\title{
PEMBELAJARAN RAMBU LALU LINTAS DENGAN MEDIA GAME ANDROID PADA SISWA SMP KELAS VII STUDI KASUS SMP DI KABUPATEN SIDOARJO
}

\author{
Muhammad Arief Kurniawan ${ }^{1}$, Agus Budi Purwantoro' ${ }^{2}$, Rukman Tea ${ }^{3}$ \\ Program Studi Manajemen Keselamatan Transportasi Jalan \\ Politeknik Keselamatan Transportasi Jalan \\ Jalan Semeru No.3 Kota Tegal, Jawa Tengah 52125 \\ E-mail: ariefkurniawan5421@gmail.comm
}

\begin{abstract}
Abstrak
Salah satu penanganan guna mengurangi kecelakaan lalu lintas pada remaja di Kabupaten Sidoarjo adalah penanaman keselamatan lalu lintas jalan dengan mengenalkan pengertian rambu-rambu lalu lintas. Penelitian bertujuan untuk mengidentifikasi tingkat pengetahuan rambu-rambu lalu lintas, menguji sistem aplikasi dalam meningkatkan pengetahuan ramburambu lalu lintas dan mengetahui peningkatan pengetahuan rambu lalu lintas setelah menggunakan Aplikasi Game. Teknik pengumpulan data yang digunakan yaitu menggunakan metode eksperimen semu (quasi eksperiment). Dengan sampel siswa SMP kelas VII berjumla 270 orang. Analisis untuk meningkatkan pengetahuan menggunakan metode statistik deskriptif dan uji paired sample T test dengan IBM SPSS Statistik 22. Untuk menguji sistem Aplikasi Game Android dengan mengukur nilai rata-rata System Usabulity Scale (SUS). Hasil peningkatan nilai rata-rata 29,28 pengetahuan rambu lalu lintas dengan hasil paired sample $T$ test nilai sig. (2-tailed) adalah sebesar 0,000<0,01 maka terdapat pengaruh Aplikasi Game Android dan hasil SUS 72,5 yaitu Aplikasi Game Android dapat diterima oleh responden.
\end{abstract}

Kata kunci: Pembelajaran, Rambu lalu lintas, Game Android, eksperimen semu, System Usabulity Scale

\section{PENDAHULUAN}

Kabupaten Sidoarjo merupakan Kabupaten yang memiliki kecelakaan lalu lintas tergolong tinggi di Jawa Timur. Tercatat bahwa tahun 2018 terdapat 1.518 peristiwa kecelakaan hal ini meningkat 4,98 persen dari tahun sebelumnya dan kecelakaan tertinggi didominasi pada usia produktif yaitu pada usia 16 tahun sampai 30 tahun (Satlantas Polresta Sidoarjo, 2018 dalam Surya 2019). Menurut Satlantas Polresta Sidoarjo(2018 dalam Surya 2019), bahwa kecelakaan lalu lintas yang dialami oleh pelajar di Kabupaten Sidoarjo menduduki peringkat ke dua tertinggi dengan jumlah 129 pelajar. Menurut Eka Kurniati(2014), bahwa banyaknya fenomena anak usia SD antara 7-12 tahun maupun SMP/ SMA 12-16 tahun dengan mudahnya mengendarai sepeda motor di jalan raya tanpa pengawasan dari orang tua maupun orang dewasa. $\mathrm{Hal}$ ini sangat berbahaya karena emosi masa remaja serta pengalaman berkendara yang masih sedikit dikarenakan pemahaman mereka tentang keselamatan lalu lintas lebih minim (Kurniati, 2014). Pelajar merupakan aset bangsa yang perlu untuk dijaga. Dengan tingginya angka kecelakaan yang dialami oleh remaja perlu ada sebuah penanganan untuk mengurangi kecelakaan. Salah satu penanganan guna mengurangi kecelakaan lalu lintas pada remaja adalah penanaman keselamatan lalu lintas jalan dengan mengenalkan pengertian rambu-rambu lalu lintas.

Penanaman pengetahuan tentang keselamatan lalu lintas perlu diterapkan secara dini 
mulai dari pendidikan formal, lingkungan rumah, dan keluarga yang mengajarkan untuk berkeselamatan. Menurut Damayati(2017), bahwa pembelajaran dengan pengenalan rambu lalu lintas pada siswa SMP berpengaruh terhadap perilaku tertib di jalan raya. Sekolah yang menjadi lembaga pendidikan perlu untuk mengajarkan pentingnya keselamatan lalu lintas. Namun, di Kabupaten Sidoarjo masih belum menyisipkan materi keselamatan lalu lintas jalan dalam kurikulum pendidikan.

Teknologi pendidikan yang semakin berkembang membuat semakin beragamnya teknik pembelajaran. Salah satunya dengan menggunakan media elektronik. Android merupakan salah satu media elektronik yang paling populer oleh semua kalangan, karena dengan sistem pengoprasian yang mudah dan banyak sajian yang ditampilkan. Pemanfaatan Android sebagai media pembelajaran yaitu salah satunya adalah dengan menggunakan sajian aplikasi berupa permainan. Menurut Dewi(2012), bahwa media pembelajaran permainan Android layak digunakan sebagai media dalam proses pembelajaran. Dengan mengembangkan suatu permainan yang bertujuan untuk mengedukasi responden maka dapat mempercepat pengetahuan tentang konten yang disajikan pada aplikasi permainan tersebut. Oleh karena itu dengan permasalahan kurangnya pengetahuan lalu lintas remaja usia 12-16 tahun maka media pembelajaran memlalui aplikasi Android cukup menarik untuk dikaji.

\section{METODE PENELITIAN}

\section{Populasi dan Sampel}

Populasi dalam penelitian ini adalah semua siswa SMP kelas VII di Kabupaten Sidoarjo. Sampel adalah baigan populasi yang ditentukan dengan metode Isaac dan Michael dalam Sugiyono, 2007 dengan total populasi siswa SMP kelas VII pada tahun 2017 berjumlah 35.566 siswa menurut keterangan Kepala Bidang SDM Dinas Pendidikan Kabupaten Sidoarjo. Pengambilan sampel pada penelitian ini menggunakan rumus Isaac dan Michael dengan taraf kesalahan sebesar 10\%. Diketahui berdasarkan tabel Isaac dan Michael yaitu sebesar 269 sampel siswa SMP kelas VII . Berikut potongan dari tabel Isaac dan Michael.

Tabel 1. Potongan Tabel Isaac dan Michael

\begin{tabular}{llll}
\hline $\mathbf{N}$ & \multicolumn{3}{c}{ Siginifikasi } \\
\cline { 2 - 4 } & $\mathbf{1 \%}$ & $\mathbf{5 \%}$ & $\mathbf{1 0 \%}$ \\
$\mathbf{1 5 0 0 0}$ & 635 & 340 & 266 \\
$\mathbf{2 0 0 0 0}$ & 642 & 342 & 267 \\
$\mathbf{3 0 0 0 0}$ & 649 & 344 & 268 \\
$\mathbf{4 0 0 0 0}$ & 653 & 345 & 269 \\
$\mathbf{7 5 0 0 0}$ & 658 & 346 & 270 \\
\hline
\end{tabular}

Sumber : Sugiyono, 2007

Berdasarkan tabel diatas dari 269 sampel dibagi ke 3(tiga) SMP yang terpilih maka sampel dibulatkan menjadi 270 siswa SMP kelas VII. Dari ke tiga SMP tersebut diambil sebanyak 90 siswa SMP kelas VII pada tiap SMP, sehingga didapatkan jumlah total 
270 sampel siswa SMP kelas VII yang melaksanakan uji pre test, treatment dan uji post test. Adapun uraian sampel adalah sebagai berikut

- SMP Negeri 3 Sidoarjo

- SMP PGRI 16 Sidoarjo

- SMP Muhammadiyah 1 Sidoarjo

\section{Teknik Pengumpulan Data}

Teknik pengumpulan data pembelajaran rambu-rambu lalu lintas siswa SMP kelas VII di Kabupaten Sidoarjo dengan media Aplikasi Game Android menggunakan metode eksperimen semu (quasi eksperiment). Eksperimen Semu (quasi eksperiment) adalah rancangan penelitian eksperimen yang dilakukan pada kondisi yang tidak memungkinkan mengontrol atau memanipulasikan semua variabel yang relevan (Danim, 2013 dalam Artikel Humas Universitas Negeri Makassar, 2018). Dengan tahapan sebagai berikut.

\section{Uji Validitas dan Reliabilitas Instrumen}

Dilakukan uji validitas pada 39 soal rambu-rambu lalu lintas dan dieliminasi sesuai dengan hasil uji validitas dengan SPSS 22 . Uji validitas dilakukan pada responden yang memiliki kriteria atau ciri yang sama dan dapat menggambarkan responden tersebut (Ambarwati, 2018). Penyebaran kuesioner yang akan diuji validitas dilakukan pada 20 siswa kelas VII SMPN 18 Margadana. Dari hasil uji validitas diketahui bahwa terdapat 22 soal valid dengan nilai r-hitung diatas r-tabel. Apabila r-hitung lebih besar dari rtabel, maka instrumen penelitian valid (Sugiyono, 2007). Dari 22 soal yang valid dieliminasi menjadi 20 soal pilihan ganda yang di input pada App Inventor2 untuk dijadikan suatu aplikasi permainan tebak rambu-rambu lalu lintas dan digunakan sebagai soal pre-tes pos-tes dalam pengukuran tingkat pengetahuan siswa SMP di Kabupaten Sidoarjo.

Adapun hasil reliabilitas bertujuan untuk mengetahui sejauh mana alat ukur dapat dipercaya dan diandalkan (Sugiyono, 2007). Tujuan untuk mengetahui sejauh mana pengukuran dapat memberikan hasil yang konsisten, menunjukan tingkat ketepatan, keakuratan bila dilakukan dua kali atau lebih terhadap subjek dengan mengunakan alat ukur yang sama rumusan koefesien reliabilitas untuk instrumen penelitian yang berupa skor berskala ukur ordinal, digunakan persamaan koefesien-a Cronbach. Berikut merupakan hasil uji reliabilitas dengan IBM SPSS Statistik 22.

Tabel 2. Hasil persamaan koefesien-a Cronbach Uji Reliabilitas

\begin{tabular}{cc}
\hline Cronbach's Alpha & N of Items \\
\hline $\mathbf{0 , 6 8 6}$ & 40 \\
\hline
\end{tabular}

Sumber : Hasil Analisis, 2019

Berdasarkan tabel diatas diperoleh nilai koefisien reliabilitas alpha sebesar 0,686. Sesuai dengan kriteria reliabilitas menurut Guilford (dalam Anwar Hidayat, 2012) bahwa skala yang memiliki nilai reliabilitas 0,40- $<0.7$ dikatakan cukup erat (reliabel), dengan demikian dapat dikatakan bahwa instrumen penelitian ini layak digunakan dalam penelitian. 


\section{Rancang Bangun Aplikasi}

Setelah dipilih 20 soal tentang rambu lalu lintas diuji validitas dan reliabitas maka selanjutnya membuat rancang bangung Aplikasi Game Android tebak rambu lalu lintas. Berikut tampilan Aplikasi Game Android tebak ramu lalu lintas.

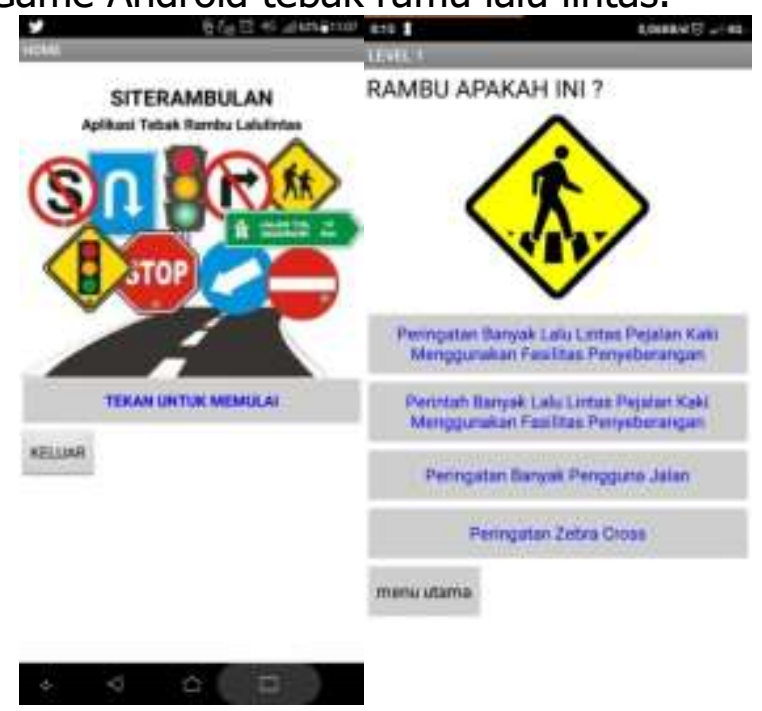

Sumber : Hasil Analisis, 2019

Gambar 1. Tampilan Aplikasi Game Android Tebak Rambu Lalu Lintas

Gambar diatas merupakan tampilan Aplikasi Game Android tebak rambu lalu lintas yang menjadi media treatment kepada siswa SMP kelas VII. Dalam Aplikasi ini memiliki jenis genre Quis Game pilihan ganda dengan jumlah soal 20. Beriku flowchart pada Aplikasi Game Android tebak rambu.



Gambar 2. Flowcart Aplikasi Game Android Tebak Rambu

Berdasarkan gambar diatas dapat diketahui bahwa alur logika yang diterapkan pada aplikasi permainan tebak rambu berupa 20 tahapan soal permainan tebak gambar. 
Sistem kerja Aplikasi permainan tebak rambu ini berupa pengulangan jika jawaban pilihan ganda $a, b, c$ atau d tidak tepat. Sebelum pengguna mengulang ke tahap awal maka pengguna akan diberikan informasi pengertian rambu yang sebenarnya. Sehingga pengguna akan mengetahui arti rambu yang salah.

3. One Group Pretest-Posttest Design

Metode One Group Pretest-Posttest Design (Tiro dan Ahmar, 2014 dalam Fatimah 2018). Ilustrasi desain penelitian adalah sebagai berikut.

Tabel 3. Desain Penelitian One Group Pretest-Posttest Design

\begin{tabular}{ccc}
\hline Pretest & Treatment & Posttest \\
\hline $\mathbf{O}_{1}$ & $\mathrm{X}$ & $\mathrm{O}_{2}$ \\
\hline Sumber : Ridwan 2018 & & \\
\hline
\end{tabular}

Sumber : Ridwan, 2018

Keterangan :

$\mathrm{O}_{1}=$ Nilai Pretest, yaitu nilai tes hasil belajar siswa sebelum menerapkan pembelajaran dengan media aplikasi permainan Android tebak rambu.

$X=$ Treatment (perlakuan), yaitu menerapkan pembelajaran dengan media aplikasi permainan Android tebak rambu.

$\mathrm{O}_{2}=$ Nilai Posttest, yaitu nilai tes hasil belajar siswa setelah menerapkan pembelajaran dengan media aplikasi permainan Android tebak rambu.

Dari hasil Pretest-Posttest akan diketahui peningkatan pengetahuan siswa SMP di Kabupaten Sidoarjo. Sehingga dapat diketahui bahwa permainan dengan menggunakan media Game Android dapat meningkatkan pengetahuan siswa SMP di Kabupaten Sidoarjo.

\section{Teknik Analisis Data}

Analisis untuk meningkatkan pengetahuan siswa SMP di Kabupaten Sidoarjo menggunakan metode statistik deskriptif dan uji paired sample $T$ test dengan menggunakan IBM SPSS Statistik 22. Menurut Sugiyono(2007) statistik deskriptif adalah statistik yang digunakan untuk menggambarkan atau menganalisis suatu statistik hasil penelitian, tetapi tidak digunakan untuk membuat kesimpulan yang lebih luas(generalisasi/inferensi). Sedangkan menurut Sahid Raharjo(2018) uji paired sample $t$ test merupakan bagian dari uji hipotesis komparatif atau uji perbandingan yang bertujuan untuk mengetahui apakah terdapat perbedaan rata-rata dua sampel (dua kelompok) yang saling berpasangan atau beruhubungan. Dalam hal ini uji t test yang dilakukan bertujuan untuk mengetahui perbedaan rata-rata sampel pretes dan postes pengetahuan rambu rambu lalu lintas.

Pada tahap analisis aplikasi menggunakan metode usability testing. metode usability testing adalah pengujian untuk menjelaskan atau mengukur seberapa mudah penggunaan suatau antar muka (interface). Pengukuran nilai dalam pengujian usability menggunakan Skala Linkert. Skala Likert dirancang untuk meyakinkan responden menjawab dalam berbagai tingkatan pada setiap butir pertanyaan atau pernyataan yang terdapat dalam kuesioner. Data tentang dimensi dari variabel-variabel yang dianalisis dalam penelitian ini yang ditujukan kepada responden menggunakan skala 1 
s/d 5 untuk mendapatkan data yang bersifat ordinal dan diberi skor sebagai berikut :

Tabel 4. Tabel Nilai

\begin{tabular}{cccccc}
\hline PK & KSS & KS & CS & S & SS \\
\hline Nilai & 1 & 2 & 3 & 4 & 5 \\
& & & & & \\
\hline
\end{tabular}

Keterangan

$\begin{array}{llll}\text { PK } & =\text { Pertanyaan Kuisioner } & \text { CS } & =\text { Cukup Setuju } \\ \text { KSS } & =\text { Kurang SetujuSekali } & \text { S } & =\text { Setuju } \\ \text { KS } & =\text { Kurang Setuju } & \text { SS } & =\text { Sangat Setuju }\end{array}$

Plot penilaian aspek usability terdapat pada formulir yang terlampir dengan 10 item pertanyaan. Dari 10 item pertanyaan dihitung nilai SUS (Systen Usability Score). Perhitungan nilai SUS dengan cara memberikan bobot untuk setiap item akan berkisar dari 0 sampai 4. Berikut perhitungan bobot untuk item.

a. Untuk item no $1,3,5,7$, dan 9 nilai yang didapat adalah posisi skala dikurangi 1 .

b. Untuk item 2, 4, 6, 8, dan 10, nilai yang didapat adalah 5 dikurangi posisi skala.

Kemudian jumlah nilai yang didapat dan dilakukan proses perhitungan nilai jumlah dikalikan 2,5 untuk mendapatkan nilai keseluruhan skor SUS. Skor SUS memiliki rentan nilai 0-100. Untuk mengetahui kualitas perangkat lunak yang dibuat, dirujuk ke grafik precentile rank terhadap SUS score berikut ini. Untuk kasus ini nilai SUS yang didapat dari rata-rata nilai yang didapat dari responden. Perhitungan nilai rata menggunakan persamaan berikut.

$$
\text { Nilai rata }- \text { rata }=\sum_{i=1}^{n} \frac{X i}{N}
$$

Dimana :

$\mathrm{Xi} \quad=$ Nilai Skor Responden

$\mathrm{N} \quad=$ Jumlah Responden 


\section{HASIL DAN PEMBAHASAN}

Adapun hasil penelitian dan pembahasan pembelajaran siswa SMP kelas VII di Kabupaten Sidoarjo adalah sebagai berikut:

Tabel 5. Hasil Analisis 270 Orang Sampel Siswa SMP Kelas VII Kabupaten Sidoarjo

\begin{tabular}{lccccccr}
\hline & $\mathrm{N}$ & Range & $\begin{array}{c}\text { Minimu } \\
\mathrm{m}\end{array}$ & $\begin{array}{c}\text { Maximu } \\
\mathrm{m}\end{array}$ & Sum & \multicolumn{2}{c}{ Mean } \\
\cline { 2 - 8 } & Statistic & Statistic & Statistic & Statistic & Statistic & Statistic & Std Error \\
\hline pretest & 270 & 80,00 & 15,00 & 95,00 & 15385,00 & 56,9815 & 1,03008 \\
Posttest & 270 & 70,00 & 30,00 & 100,00 & 23290,00 & 86,2593 &, 57809 \\
$\begin{array}{l}\text { Valid N } \\
\text { (listwise) }\end{array}$ & 270 & & & & & & \\
\hline
\end{tabular}

Sumber : Hasil Analisis, 2019

Tabel 6. Rekapitulasi Hasil Uji pre Test dan Post Test Pembelajaran Rambu Lalu Lintas dengan Media Game Android pada Siswa SMP di Kabupaten Sidoarjo.

\begin{tabular}{|c|c|c|c|c|}
\hline \multirow[t]{2}{*}{ No } & \multirow[t]{2}{*}{ Jenis Responden } & \multicolumn{2}{|c|}{ Hasil } & \multirow{2}{*}{$\begin{array}{c}\text { Selisih } \\
(+)\end{array}$} \\
\hline & & Pre Test & $\begin{array}{l}\text { Post } \\
\text { Test }\end{array}$ & \\
\hline $\mathbf{1}$ & $\begin{array}{l}\text { Seluruh siswa SMP kelas VII di Kabupaten } \\
\text { Sidoario. }\end{array}$ & 56,9815 & 86,2593 & 29,28 \\
\hline 2 & Siswa laki-laki SMP kelas VII di Kabupaten Sidoarjo & 54,4964 & 85,5755 & 27,37 \\
\hline 3 & $\begin{array}{l}\text { Siswa perempuan SMP kelas VII di Kabupaten } \\
\text { Sidoarjo }\end{array}$ & 59,6183 & 86,9847 & 27,37 \\
\hline 4 & Siswa SMPN 3 Sidoarjo kelas VII & 64,7222 & 88,5000 & 23,78 \\
\hline 5 & Siswa laki-laki SMPN 3 Sidoarjo kelas VII & 64,5455 & 88,7500 & 24,20 \\
\hline 6 & Siswa perempuan SMPN 3 Sidoarjo kelas VII & 64,8913 & 88,2609 & 23,37 \\
\hline 7 & Siswa SMP Muhammadiyah 1 Sidoarjo kelas VII & 55,3333 & 86,8333 & 31,5 \\
\hline 8 & $\begin{array}{l}\text { Siswa laki-laki SMP Muhammadiyah } 1 \text { Sidoarjo } \\
\text { kelas VII }\end{array}$ & 52,7500 & 85,5000 & 32,75 \\
\hline 9 & $\begin{array}{l}\text { Siswa perempuan SMP Muhammadiyah } 1 \text { Sidoarjo } \\
\text { kelas VII }\end{array}$ & 57,4000 & 87,9000 & 30,5 \\
\hline 10 & Siswa SMP PGRI 16 Sidoarjo kelas VII & 50,8889 & 83,4444 & 32,56 \\
\hline 11 & Siswa laki-laki SMP PGRI 16 Sidoarjo kelas VII & 47,7273 & 83,0909 & 35,36 \\
\hline 12 & Siswa perempuan SMP PGRI 16 Sidoarjo kelas VII & 55,8571 & 84,0000 & 28,14 \\
\hline
\end{tabular}

Sumber : Hasil Analisis, 2019

Berdasarkan hasil analisis pre test dan post test dengan IBM SPSS Statistik 22 terlihat bahwa nilai rata-rata pre test 56,9815 dari skor ideal 100 dengan deviasi standar 16,92592 . Adapun hasil nilai terendah dari pre testadalah 15 dan nilai tertinggi adalah 95 dengan selisih/rentang skor 80 . Dari hasil nilai pre test dapat diketahui bahwa pengetahuan siswa SMP kelas VII di Kabupaten Sidoarjo memiliki rata-rata nilai 56,98 sebelum mendapatkan pelajaran dengan media Aplikasi Game Android tebak rambu. Nilai rata-rata post test 86,2593 dari skor ideal 100 dengan deviasi standar 9,49894. Adapun hasil nilai terendah dari post test adalah 30 dan nilai tertinggi adalah 95 
dengan selisih/rentang skor 80 . Selisih nilai rata-rata pre test dan post testyaitu 29,28 maka dapat diketahui bahwa pembelajaran rambu-rambu lalu lintas dengan media Aplikasi Game Android tebak rambu pada siswa SMP kelas VII di Kabupaten Sidoarjo meningkatkan pengetahuan dengan kenaikan nilai 29,28. Dalam penelitian ini juga terdapat perbedaan kenaikan pengetahuan nilai dari 3(tiga) jenis SMP yang berbeda yaitu SMPN 3 Sidoarjo yang mewakili SMP Negeri dengan hasil pre test 64,5455; post test 88,5000; selisih rata-rata 23,78. SMP Muhammadiyah 1 Sidoarjo yang mewakili SMP dengan pendidikan Agama dengan hasil pre test 55,3333; post test 86,8333; selisih rata-rata 31,5. dan SMP PGRI 16 Sidoarjo mewakili SMP Swasta dengan hasil pre test 50,8889; post test 83,4444; selisih rata-rata 32,56.

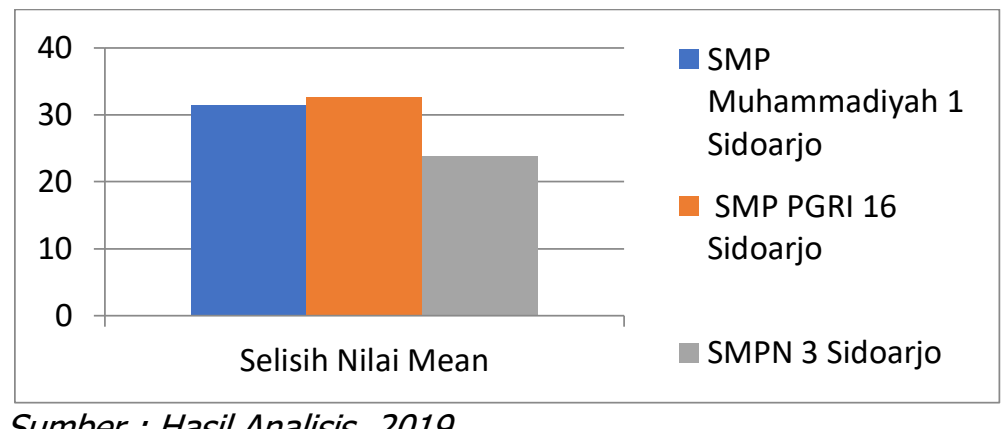

Sumber : Hasil Analisis, 2019

Gambar 3. Grafik Peningkatan Nilai Rata-Rata Pengetahuan Tentang Rambu Lalu Lintas

Berdasarkan gambar diatas dapat diketahui bahwa SMP PGRI 16 Sidoarjo memiliki kenaikan nilai rata-rata tertinggi setelah treatment dengan permainan Game Android tebak rambu lalu lintas yaitu dengan kenaikan nilai rata-rata 32,56. Sedangkan untuk SMPN 3 Sidoarjo memiliki tingkat kenaikan nilai rata-rata terendah dengan nilai ratarata 23,78. Hasil tersebut dikarenakan bahwa pengetahuan dasar siswa SMPN 3 Sidoarjo tentang rambu lalu lintas lebih tinggi dari SMP PGRI 16 Sidoarjo dengan nilai rata-rata pre test 64,5455 sedangkan SMP PGRI 16 Sidoarjo memiliki nilai rata-rata pre test 50,8889. Sehingga mengakibatkan selisih rata-rata post test dan pre test SMPN 3 Sidoarjo lebih kecil dibanding SMP Muhammadiyah 1 Sidoarjo dan SMP PGRI 16 Sidoarjo. Dari hasil tersebut dapat diketahui bahwa pengetahuan dasar tentang rambu-rambu lalu lintas responden siswa kelas VII SMPN 3 Sidoarjo lebih tinggi dibanding responden siswa kelas VII SMP Muhammadiyah 1 Sidoarjo dan SMP PGRI 16 Sidoarjo.

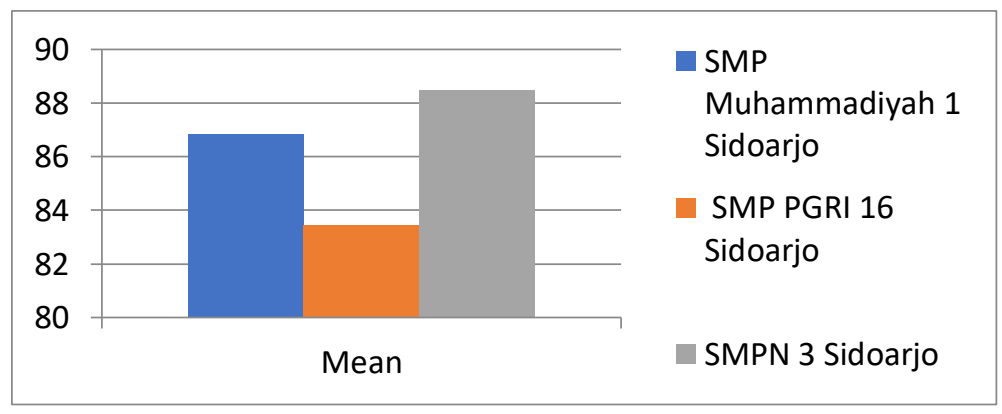

Sumber : Hasil Analisis, 2019

Gambar 4. Grafik Nilai Rata-rata Post Test

Berdasarkan gambar diatas dapat diketahui bahwa nilai rata-rata post test tertinggi 
yaitu pada SMPN 3 Sidoarjo dengan nilai rata-rata 88,5. Sedangkan nilai rata-rata post test terendah pada SMP PGRI 16 Sidoarjo dengan nilai rata-rata 83,4. Perbedaan nilai antara SMPN 3 Sidoarjo dan SMP PGRI 16 Sidoarjo adalah 5,1.

Pada tahap uji paired sample $t$ test menggunakan IBM SPSS statistik 22 dengan menggunakan tingkat kepercayaan $95 \%$ atau signifikansi $5 \%$ atau 0,05 . Dalam uji paired sample $t$ test menggunakan hipotesis sebagai berikut.

$\mathrm{HO}=$ tidak ada perbedaan rata-rata antara hasil pre test dengan post test yang artinya tidak ada pengaruh penggunaan startegi pembelajaran dengan menggunakan aplikasi Game Android tebak rambu lalu lintas dalam meningkatkan pengetahuan rambu lalu lintas pada siswa kelas VII SMP di Kabupaten Sidoarjo.

$\mathrm{Ha}=$ ada perbedaan rata-rata antara hasil pre test dengan post test yang artinya ada pengaruh penggunaan startegi pembelajaran dengan menggunakan aplikasi Game Android tebak rambu lalu lintas dalam meningkatkan pengetahuan rambu lalu lintas pada siswa kelas VII SMP di Kabupaten Sidoarjo.

Pengambulan keputusan Uji paired sample $t$ test berpedoman pada pedoman pengambilan keputusan uji paired sample t test menurut (singgih santoso, 2014:265 dalam Sahid Raharjo 2018) dengan hasil output SPSS, adalah sebagai berikut.

1. Jika nilai Sig. (2-tailed) $<0,05$, maka HO ditolak dan Ha diterima.

2. Sebaliknya, jika nilai Sig. (2-tailed) >0,05, maka HO diterima dan Ha ditolak.

Untuk mengetahui hasil dari pre test dan post test pembelajaran rambu lalu lintas dengan media Game Android tebak rambu maka dilakukan uji paired sample $t$ test. Berikut adalah hasil uji paired sample $t$ test IBM SPSS Statistik 22.

Tabel 7. Hasil Paired Sample T Test

\begin{tabular}{|c|c|c|c|c|c|}
\hline & & $\begin{array}{c}\text { Paired Differences } \\
\text { 95\% Confidence Interval } \\
\text { of the Difference } \\
\text { Upper }\end{array}$ & $\bar{T}$ & Df & $\begin{array}{l}\text { Sig. (2- } \\
\text { tailed) }\end{array}$ \\
\hline Pair 1 & $\begin{array}{l}\text { Pre Tes - } \\
\text { Pos Tes }\end{array}$ & $-27,13248$ & $\begin{array}{r}- \\
26,86 \\
9\end{array}$ & 269 & ,000 \\
\hline
\end{tabular}

Sumber : Hasil Analisis, 2019

Berdasarkan tabel output "Paired Sample Test" di atas, diketahui nilai Sig. (2-tailed) adalah sebesar 0,000 0,01 maka HO ditolak dan Ha diterima. Sehingga dapat disimpulkan bahwa ada perbedaan rata-rata antara hasil pre test dengan post test yang artinya ada pengaruh penggunaan startegi pembelajaran dengan menggunakan aplikasi Game Android tebak rambu lalu lintas dalam meningkatkan pengetahuan rambu lalu lintas pada siswa kelas VII SMP di Kabupaten Sidoarjo.

Pada tahap uji usability menggunakan penentuan grade nilai System Usabulity Scale (SUS) yang dikembangkan oleh Brooke, 2013 dalam (Ependi Febriyanti; Hutrianto dan Hutrianto, 2017) dimana penentuan grade dilihat dari sisi tingkat penerimaan pengguna, grade skala dan adjektif rating. Dengan hasil rata-rata usability 72,5 dengam jumlah responden 30 siswa SMP di Kabupaten Sidoarjo. Berikut adalah penentuan dari grade nilai System Usabulity Scale (SUS). 


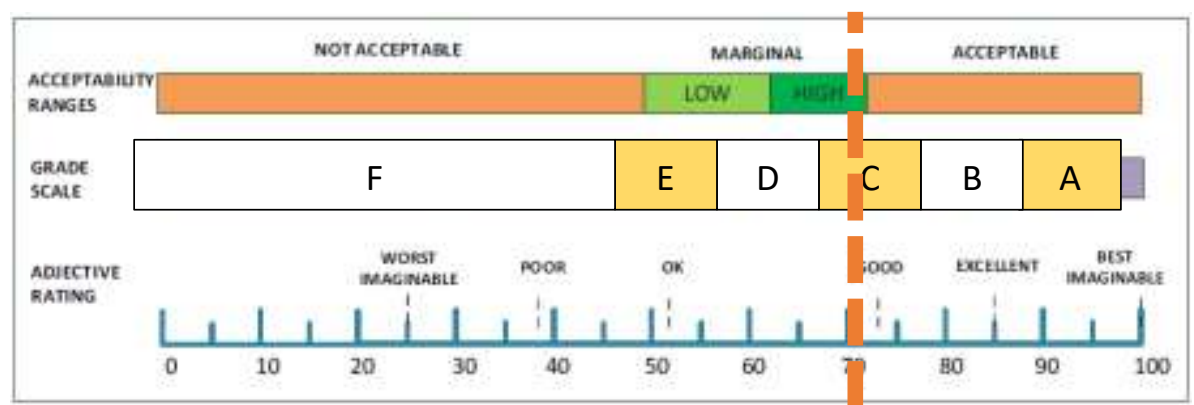

Sumber : Brooke, 2013 dalam (Ependi Febriyanti; Hutrianto dan Hutrianto, 2017)

Gambar 5. Grade Penilaian System Usability Scale (SUS)

Berdasarkan tabel diatas dapat diketahui bahwa skor SUS Aplikasi Game Android tebak rambu lalu lintas dengan nilai rata-rata SUS 72,5 termasuk dalam kategori grade sebagai berikut :

a. Acceptability yaitu tingkat penerimaan pengguna masuk dalam kategori acceptable. Maka dapat didefinisikan bahwa responden menerima Aplikasi Game Android tebak rambu lalu lintas.

b. Grade scale yaitu tingkat grade skala masuk dalam kategori C. Maka kualitas Apikasi Game Android tebak rambu lalu lintas termasuk kategori grade C.

c. Adjective rating yaitu adjective rating masuk dalam kategori good maka sifat dalam Aplikasi Game Android tebak rambu lalu lintas tergolong bersifat bagus.

\section{PENUTUP}

\section{Simpulan}

1. Dengan nilai rata-rata pengetahuan 56,98 maka dapat diketahui bahwa pengetahuan dasar tentang rambu lalu lintas siswa SMP di Kabupaten Sidoarjo masih sangat minim. Hasil identifikasi tingkat pengetahuan rambu lalu lintas siswa SMP kelas VII di Kabupaten Sidoarjo setelah pembelajaran media Aplikasi Game Android tebak rambu yaitu dengan rata-rata nilai 86,26 . Secara umum diketahui bahwa pengetahuan rambu-rambu lalu lintas setelah pembelajaran dengan media Game Android meningkat.

2. Hasil uji sistem aplikasi berdasarkan hasil Usability dengan nilai rata-rata System Usabulity Scale (SUS) 72,5 bahwa perangkat lunak mempunyai kualitas yang baik dikarenakan nilai SUS ?70 (Pudjoatmodjo dan Wijaya, 2016). Sehingga Aplikasi Game Android tebak rambu lalu lintas tidak perlu dilakukan perancangan sistem ulang. Dengan grade tingkat penerimaan pengguna masuk dalam kategori acceptable yaitu aplikasi dapat di terima oleh responden. Tingkat grade skala masuk dalam kategori $\mathrm{C}$. Adjective rating masuk dalam kategori good yaitu sifat aplikasi menurut responden tergolong bagus. Sesuai dari hasil penilaian tersebut maka aplikasi dapat diterima baik oleh responden.

3. Peningkatan pengetahuan rambu lalu lintas siswa SMP kelas VII di Kabupaten Sidoarjo setelah pembelajaran dengan media Aplikasi Game Android tebak rambu dengan hasil peningkatan nilai rata-rata 29,28 dan didukung oleh uji paired test dengan hasil nilai Sig. (2-tailed) adalah sebesar 0,000<0,05 maka ada pengaruh penggunaan startegi pembelajaran dengan menggunakan aplikasi Game Android tebak rambu lalu lintas dalam meningkatkan pengetahuan rambu lalu lintas pada siswa kelas VII SMP di Kabupaten Sidoarjo. 


\section{Saran}

1. Tingkat pengetahuan tentang rambu lalu lintas siswa SMP kelas VII di Kabupaten Sidoarjo sebelum ada pembelajaran dengan media Aplikasi Game Android tebak rambu tergolong masih minim dikarenakan hasil rata-rata nilai 56,98. Maka perlu adanya pembelajaran tentang arti simbol dan warna rambu lalu lintas kepada siswa SMP kelas VII sehingga dapat meningkatkan pengetahuan tentang rambu lalu lintas.

2. Hasil peningkatan pengetahuan rambu lalu lintas dengan nilai peningkatan ratarata 29,28 maka perlu adanya pendalaman yang lebih bagi responden terkait konten Aplikasi Game Android tebak rambu lalu lintas sehingga dapat meningkatkan pengetahuan responden lebih dari nilai rata-rata 29,28.

3. Dengan nilai rata-rata SUS yang 72,5 pada aplikasi Game Android tebak rambu mendekati nilai rata-rata minimum yaitu 70. Maka perlu untuk dilakukan pengembangan dalam rancang bangun aplikasi Game Android tebak rambu agar lebih menarik untuk responden seperti penambahan variasi rambu-rambu lalu lintas.

\section{DAFTAR PUSTAKA}

Damayati, S. N. (2017). Pengaruh Integrasi Etika Lalu Lintas Dalam Pembelajaran Ips Terhadap Perilaku Tertib Di Jalan Raya Siswa Kelas Vii Smp Negeri 14 Yogyakarta, 71-81.

Dewi, G. P. F. 2012. Pengembangan Game Edukasi Pengenalan Nama Hewan Dalam Bahasa Inggris Sebagai Media Pembelajaran Siswa Sd Berbasis Macromedia Flash Skripsi.

Ependi Febriyanti; Hutrianto, Hutrianto, U. P. (2017). System Usability Scale Antarmuka Palembang Guide Sebagai Media Pendukung Asian Games XVIII. Journal of Information Systems Engineering and Business Intelligence, 3(2),pp.80-86.

Humas Universitas Negeri Makassar (2018). Penelitian Eksperimen Semu. Retrieved June 23, 2019, from https://penalaran-unm.org/penelitian-eksperimen-semu/

Ridwan, R. A. F. 2018. Efektivitas Penerapan Pendekatan Savi Setting Cooperative Script Dalam Pembelajaran Matematika Siswa Kelas IX SMP Negeri 33 Makassar.

Sahid Raharjo. (2018). Cara Uji Paired Sample T-Test dan Interpretasi dengan SPSS SPSS Indonesia. [Online] Tersedia di from https://www.spssindonesia.com/2016/08/cara-uji-paired-sample-t-testdan.html[Diakses pada tanggal 3 Agustus 2019

Sugiyono. (2007). Statistik Untuk Penelitian.pdf. (E. Mulyatiningsih, Ed.) (11th ed.). Bandung: CV Alfabeta. https://doi.org/10.1016/S0969-4765(04)00066-9 